\title{
"A Remedy on Paper": \\ The Role of Law in the Failure of \\ City Planning in New Haven, 1907-1913
}

\author{
Mark Fenster
}

In 1924, prominent patent attorney George Dudley Seymour resigned his position on the New Haven City Plan Commission after more than a decade of frustration.' For nearly two decades, Seymour had been active in city government in virtually all local projects relating to city improvement, big and small. $^{2}$ In 1907, he helped to initiate in New Haven what would become known nationally as the "City Beautiful" movement, and his efforts led to the commission of Cass Gilbert, a well-known New York-based architect, and Frederick Law Olmsted, Jr., a nationally recognized city planner, to devise a comprehensive report on how best to improve New Haven's physical environment and infrastructure. ${ }^{3}$ In 1913, New Haven established its city planning commission, ${ }^{4}$ an event also attributable in great part to Seymour's efforts, and Seymour was ultimately appointed as the commission's first secretary. ${ }^{5}$ By 1924, however, the realization of Seymour's vision of an efficient and rational city planning commission seemed an impossibility.

Early city planning in New Haven was part of a larger national movement by professional and economic elites and by government officials to change

1. See Seymour Quits Board; Charges Law Ignored, NEw HAveN J.-COURıER, July 23. 1924, at I [hereinafter Seymour Quirs Board] (printing Seymour's letter of resignation), reprinted in GEORGE DUDLEY SEYMOUR, NEW HAVEN 590 (1942).

2. See Ralph L. Pearson \& Linda Wrigley, Before Mayor Richard Lee: George Dudley Seymour und the City Planning Movement in New Haven, J907-1924, 6 J. URB. HIST. 297, 309-12 (1980).

3. The report was ultimately published as CASS GILBERT \& FREDERICX LAW OLIISTED. REPORT OF THE NEW HAVEN CIVIC IMPROVEMENT COMMISSION TO THE NEW HAVEN CIVIC IMPROVEMENT COMMITTE (1910).

4. See New Haven, Conn., An Act Amending the Charter of the City of New Haven and Creating a City Plan Commission (May 28, 1913).

5. See infra text accompanying note 152 . 
what they perceived to be increasingly uncivilized, unruly, and inefficient cities into more disciplined, rationally ordered urban centers of industry, commerce, and modernity. ${ }^{6}$ Supported by a city's middle and upper classes, ${ }^{7}$ as well as by its chamber of commerce and other civic organizations, ${ }^{8}$ early city planning did not constitute a radical reconsideration of the existing private land use regime. ${ }^{9}$ Nevertheless, planners faced an important conflict between powerful notions of individual property rights ${ }^{10}$ and the city's needs as a collective entity-including capital's need for rationality and efficiency in the city's economic and physical infrastructure, and city patricians' sense that parks and beautiful boulevards were crucial to citizens' health and well-being.

According to architectural critic and city planning advocate Lewis Mumford, the national City Beautiful movement posed only "a remedy on paper" for problems that required "a thorough reorganization of the community's life." Although it produced reams of reports, newspaper articles, and minutes of civic organization and municipal government meetings, early city planning in New Haven, as in many other cities, did not successfully effect a systematic solution to the urban crises it identified. ${ }^{12}$ As Seymour bitterly complained in an open letter to the Mayor of New Haven, "Not having

6. See M. Christine Boyer, DREaming the Rational CITY: THE MYTH OF CitY PlanNing 31-32 (1983) [hereinafter BOYER, DREAMING]; PAUl BOYER, URBAN MASSES AND MORAL ORder IN AMERICA. 1820-1920, at 263-70 (1978) [hereinafter BOYER, URBAN MASSES]. French sociologist Henri Lefebvre has argued that city planning decontextualizes and dehistoricizes urban space, ideologically substituting concems about spatial order for the questioning of existing political, economic, and social order. See Henri Lefebvre, Philosophy of the City and Planning Ideology, in WRITINGS ON CITIES 97, 97-99 (Eleonone Kofman \& Elizabeth Lebas eds. \& trans., 1996). In addition, legal doctrines of property similarly impose notions of order (in the form of common law principles and statutory form) upon historically rich and materially complex spaces. See NICHOLAS K. BLOMLEY, LAW, SPACE, AND THE GEOGRAPHIES OF POWER 53 (1994).

7. See, e.g., MANSEl G. Blackford, The Lost DREam: Businessmen and City PlanNing on the PACIFIC COAST, 1890-1920, at 151-59 (1993) (discussing the role of businessmen in city planning movements in San Francisco, Seattle, and other West Coast cities).

8. See Benjamin Clarke Marsh, AN Introduction to City Planning: Democracy's Challende TO THE AMERICAN CITY 138-43 (1909) (noting that private civic groups initiated local civic improvement and planning movements in several cities).

9. See Mel SCOTt, American CtTy Planning Since 1890, at 75 (1969). For example, the carliest city planners associated with the City Beautiful movement rarely showed interest in building public housing. See Keith Aoki, Race, Space, and Place: The Relation Between Architectural Modernism, Post. Modernism, Urban Planning, and Gentrification, 20 FORDHAM URB. L.J. 699, 711 (1993); Peter Marcuse, Housing in Early City Planning, 6 J. URB. HIST. 153, 158 (1980).

10. See Richard E. Foglesong, Planning the Capitalist City: The Colonial Era to the 1920 s, at 230 (1986). An interesting subtext to this conflict was a belief among some in the movement that rationalizing and beautifying the city were necessary steps in preventing the cities' growing masses from turning to socialism. Financier Henry Morganthau's speech to the First National Conference on City Planning, in which he included socialism as one of the diseases (along with "physical disease," "moral depravity," and "discontent") from which planning would protect America, is typical in this regard. See SCOTT, supra note 9, at 96; cf. GILBERT \& OLMSTED, supra note 3, at 13 (distinguishing the report's suggestions from socialism).

11. LEWIS MUMFORd, Sticks AND STONES: A STUdY OF AMERICAN ARCHITECTURE AND CiVILIZATION 133 (1924).

12. See William H. Wilson, The City Beautiful Movement 99-280 (1989) (discussing varying levels of success and failure in different cities); see also ScoTT, supra note 9, at 182 (discussing the limited and uneven success of early city planning). 
been allowed to function as intended or to prepare a plan for the orderly development of the City, as was made mandatory by the act [creating the Commission], the Commission is undoubtedly a handicap, rather than a help,- - hindrance to public business." 13 Intended to facilitate efficiency and discipline, the city planning commission had by 1924 become a vestigial part of what Seymour considered a poorly managed municipal government. This frustration of New Haven's local movement was representative of a wider national frustration. ${ }^{14}$

Scholars trying to account for the failure of city planning in New Haven during the period prior to zoning ${ }^{15}$ have typically pointed to either a lack of political and public support ${ }^{16}$ or the effectiveness of land use coordination under the existing common law and prevailing social norms. ${ }^{17}$ Each of these related factors played a role in that failure. Resistance among some local officials and some members of the public, often arising from their satisfaction with the current land use regime, did help limit what planners and planning proponents could achieve. This Note, however, focuses on a further impediment: the limits of available legal doctrine and municipal governance for the proposal and implementation of comprehensive programs of city planning. These limits helped to define what planners could propose and the means by which cities could seek to achieve their ends.

Although they were subject to some dispute and revision, the concepts of eminent domain ${ }^{18}$ and the police power ${ }^{19}$ were fairly well-defined at the time, making it clear which regulations and government takings were permissible. ${ }^{20}$ At both the national and local levels, the limits imposed by these doctrines caused much debate and affected both the shape and

13. Seymour Quits Board, supra note 1, reprinted in SEYMOL'R, supra note 1. at 597

14. See infra Part I.

15. New Haven passed its first zoning ordinance in 1926. See New Haves CrTY Plan COMMiN. REZONING FOR NEW HAVEN 3 (1962) (recounting the development of zoning in New Haven). Chnstina G. Forbush, Striving for Order: Zoning the City of Elms (May 9. 1997) (unpublished manuscript. on file with the Whitney Library of the New Haven Colony Histoncal Soctety) (describing the carly history of zoning in New Haven).

16. See, e.g., ROBERT A. DAHL, WhO GOVERNS? DEMOCRACY AND POWER IN AN AMERICAN CTTY 116 (1961) ("A city plan commission was created [by New Haven] in 1913 but was given neither funds nor a professional staff."); Pearson \& Wrigley, supra note 2. al 310-12 (citung politics and a lack of public support for city planning).

17. See Andrew J. Cappel, Note, A Walk Along Willow: Patterns of Land Use Coordination in Pre-Zoning New Haven (1870-1926), 101 YALE L.J. 617 (1991).

18. A treatise on eminent domain from this period defined the power sımply as "the taking of pnvate property for the public use." PHILIP NICHOLS, THE POWER OF ENINENT DOMIAIN at III (1909).

19. One proponent of city planning cited a contemporary legal encyclopedia that defined the police power as a city's ability to prohibit "..'all things hurtful to the comfort. safety and welfare of soctely, and establishing such rules and regulations for the conduct of all persons. and the use and management of all property, as may be conducive to the public interest." 'Walter L. Fisher. Legal Aspects of the Plan of Chicago, Appendix to Daniel H. Burnham \& Edward H. BenNett. Plan of CilCago 12S. 129 (1909) (quoting 22 AM. \& ENG. ENCYC. LAW 916 (2d ed. 1902)): see also ERNST FRELND. THE POLICE POWER $\S 3$, at 3 (1904) (defining the police power as aiming "directly to socure and promote the public welfare, and it does so by restraint and compulsion").

20. See Stanley K. Schultz. Constrlcting Urban Clilture: Americax Cmes and Ctty PLANNING, 1800-1920, at 35-42, 75-81 (1989) 
success-or lack thereof-of early twentieth-century city planning. Furthermore, the nascent administrative bureaucracies of cities like New Haven proved to be ineffective instrumentalities for implementation of programs in the face of the constraints of formal legal doctrines. In challenging these constraints, however, planning proponents began the long process of changing legal doctrine and land use regulation. In turn, this helped to enable the rise of municipal zoning ordinances in the mid-1920 $\mathrm{s}^{21}$ and served as an important precedent for the far more radical "urban renewal" projects of New Haven in the decades after World War $\mathrm{L} .^{22}$

Part I provides an overview of the dominant conservative legal doctrines and governing practices that limited planners' goals and strategies during the period from 1907 through $1913,{ }^{23}$ and that planning advocates sought to change. Part II provides a narrative of the New Haven planning movement prior to the publication of the Gilbert-Olmsted report on city improvement in 1910. To illustrate the difficulties facing the nascent planning movement in New Haven, Part II chronicles an early attempt by planning proponents to expand the creation and enforcement of one form of land use regulation, building lines. Part III discusses the Gilbert-Olmsted report, the reaction to it, and the events that led to the establishment of a new administrative agency in New Haven devoted to city planning. Parts II and III include not only those arguments about law and municipal structure made by participants in the New Haven movement, but also those made by attorneys and lay planning proponents associated with the national planning movement. Part IV summarizes the role of law and governance in limitating upon what planners during this era could propose and what the municipal administrative agencies that planners advocated could enact and enforce. In addition, Part IV describes the relationship between the early city planning movement and the centralized city planning that would occur in the years after World War II.

\section{A "MAZE OF ObSTACles": Legal AND Municipal Stumbling Blocks FACING EARLY CITY PLANNING}

By the time of the Gilbert-Olmsted report's publication in 1910, the ascendant national planning movement had developed enough expertise to recognize the fundamental legal issues at stake in city planning and to begin to describe them in reports, conferences, and books. Two important

21. See sources cited supra note 15 .

22. On the redevelopment of New Haven in the post-war period, see DAHL, supra note 16; G. WILliam DOMHOFF, Who REAlly RULES? NEW HAVEN AND COMMUNITY POWER REEXAMined (1978);

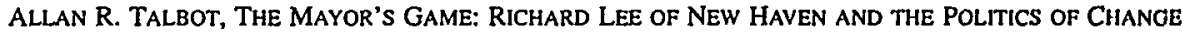
(1967); and RAYMOND E. WOLFINGER, THE POLITICS OF PROGRESS (1974).

23. The period that this Note describes runs from the commissioning of the Gilbert-Olmsted report in 1907, see infra Section II.A, to the city and state legislature's approval of a city plan commission for New Haven, see infra notes $149-151$ and accompanying text. 
developments in this regard were the establishment in 1907 of the first American city planning commission by Harford, Connecticut, ${ }^{24}$ and the inclusion of an extensive essay ${ }^{25}$ on the legal issues involved in a city plan by a prominent Chicago attorney named Walter Fisher in Daniel Burnham and Edward Bennett's celebrated 1909 Plan of Chicago. ${ }^{26}$ The establishment of the Hartford Commission represented the beginning of a national trend toward including planning within the administrative structure of municipal governments. Fisher's essay was the first in a series of attempts by members of the bar associated with the city planning movement to discuss the relationship of planning to municipal governance and the common law. ${ }^{27}$

One of the underlying themes of these legal reports was that doctrinal and political barriers in American courthouses and legislatures constituted city planning's greatest foes. As Olmsted wrote in his introduction to a book-length volume on the legal implementation of city planning, public officials and lawyers for cities faced "the constantly recurring problem of finding the way of least resistance for navigating a specific improvement through the maze of obstacles imposed by the existing local legal situation." ${ }^{28}$ These situations had given rise, according to Olmsted, to city officials' "almost fatalistic acceptance of these obstacles as a permanent condition." ${ }^{29}$ In particular, restrictive conceptions of the police power and eminent domain frustrated the planning proponents' attempts to propose and implement changes. Conservative legal views on the scope of municipal authority also thwarted the planners. John Dillon's important treatise on the municipal corporation, already in its fifth edition by $1911,{ }^{30}$ embodied this cautious approach with its concerns that the growing complexity of city charters and the expansion in municipal

24. See FOGLESONG, supra note 10, at 225-27.

25. See Fisher, supra note 19.

26. BURNHAM \& BENNETT, supra note 19.

27. For other examples of such writings, see EDWARD M. BASSETT. CONSTITLTIONAL LINITATIONS on CITY Planning Powers (1917); and Flavel Shurtueff. Carrying OUt the CtTy Plai (1914). While Fisher's appendix to Burnham and Bennett's Plan of Chicago was in circulation at the tume of the New Haven report, the legal issues at stake did not change between 1909 and the carly atternpts to establish comprehensive zoning schemes in the next decade. Legal discussions and commentanes offered consistent strategies about how to frame winning legal arguments. Other than differences in scope-due to the nature of his project, Fisher focuses far more on specific county and clity laws than either Basselt or Shurtleft-the three works are quite similar.

28. Frederick Law Olmsted, Introduction to SHURTLEF, supra note 27, at v. v-vi

29. Id. at vi.

30. See John F. Dillon, Commentaries on the Law of Municipal Corporations (5ih ed. 1911) Dillon was an important figure in the national legal community who had served as stute supreme court justice, professor of municipal law at Columbia College. counsel for the Union Pacific Raulroad. and president of the American Bar Association. See MORTON J. HORWIT. THE TRANSFORMATION OF AMERICAN LAW, 1870-1960, at 25, 97 (1992): SCHULTZ supra note 20. at 66.75. Dillon's treatuse on the municipal corporation was known in the New Haven corporation counsel's office, which ciled the "strngent and extraordinary" limitations on the power to condemn in a 1913 advisory opınıon. See Letter from Charles Kleiner, Corporation Counsel of New Haven, to the Special Commission on Building Lunes (July 8, 1913), reprinted in 1913 CTY Y.B. NEW HAVEN 808, 808-09 (quoling 3 DiLLos, supru. 1040, at 1646). 
government could endanger the sanctity of private property. ${ }^{31}$

The following two sections briefly summarize the "obstacles" of the "existing local legal situation" that planners faced.

\section{A. Legal Doctrines}

During the early part of the twentieth century, there were three legal doctrines available for planners who advocated the expansion of municipal regulation of private land use: nuisance, the police power, and eminent domain. While state courts were receptive to private plaintiffs' nuisance complaints, ${ }^{32}$ the proponents of planning saw eminent domain and the police power as far more effective means to implement public projects and city planning. Neither doctrine, however, was flexible enough to support the systematic and comprehensive redevelopment of the modern city.

Theoretically, the police power was a fairly flexible doctrine that allowed for systematic, municipally controlled land use regulation..$^{33}$ In practice, however, the doctrine's flexibility was more limited. According to the leading contemporary treatise on the subject, for example, restrictions for aesthetic purposes under the police power would "constitute a substantial impairment of the right of property, and the maintenance of an official standard of beauty would not easily be recognized under our theory of constitutional law." ${ }^{34}$ The city's ability to take land under its power of eminent domain faced even stricter federal and state constitutional limits, backed by public resistance to what Americans perceived to be the potential for governmental abuse inherent in such a power. ${ }^{35}$ American cities seeking to take land under eminent domain for planning purposes had to assert that their takings would constitute a public use of the property. ${ }^{36}$

31. See 1 DILLON, supra note $30, \S 24$, at $39-40$ (asserting that property owners "who have to bear the burden" should have a "controlling voice" over municipal management of these improvements).

32. For general discussions of nuisance law during this period, see 1 ROBERT M. ANDERSON, AMERICAN LAW OF ZONING § 3.03, at 86-90 (3d ed. 1986); Martha A. Lees, Preserving Property Values? Preserving Proper Homes? Preserving Privilege?: The Pre-Euclid Debate over Zoning for Exclusively Private Residential Areas, 1916-1926, 56 U. PITT. L. REV. 367, 371 (1994); and Cappel, supra note 17, at 629. Connecticut courts were particularly receptive to nuisance actions. See, e.g., Hurlbut v. McKone, 10 A. 164 (Conn. 1887) (barring the defense of coming to the nuisance); Whitney v. Bartholomew, 21 Conn. 213 (1851) (allowing for relief from lawful, non-negligent practices causing unreasonable damages); Nichols v. Pixly, 1 Root 129 (Conn. 1789) (barring the defense that a city license authorized noxious or hazardous activities when injury is done to private property).

33. See 2 DiLlon, supra note $30, \S 660$, at 994 (noting the lack of limits on the police power, so long as any use of such power is performed for the "public welfare"); FREUND, supra note 19, \& 3, at 3 (calling the police power "elastic" and "capable of development"). On the development of the police power in the late 19th and early 20th centuries generally, see HORWITZ, supra note 30, at 27-30; and SCHULTZ, supra note 20 , at $75-81$.

34. FREUND, supra note $19, \S 181$, at 164.

35. See 3 DILLON, supra note $30, \S 1011$, at 1601-02. On the development of eminent domain in the 19 th century, see SCHULTZ, supra note 20 , at 35-42.

36. See, e.g., JOHN LEWIS, A TREATISE ON THE LAW OF EMINENT DOMAIN IN THE UNITED STATES $\S 165$, at $415-20$ ( $2 \mathrm{~d}$ ed. 1900 ) (defining eminent domain by a "public use test"). On the tendency of jurists 
The police power and eminent domain constituted the grounds upon which planners and planning advocates could formulate legal strategies to succeed in their projects. These legal doctrines both limited planners' visions and shaped their conceptions of how to justify these visions' purposes and implementation. In asserting the legality of implementing Burnham and Bennett's Chicago plan, for example, Fisher argued that "the restraints of the fundamental law under which we live do not forbid any of the steps recommended in the proposed Plan of Chicago, although in many important respects they do fix and control the manner in which, and the means by which, these steps can be taken." ${ }^{37}$ As Burnham himself said to an international planning conference held in 1910 in London:

In a continuing democracy nothing will be done illegally: if conflict between purpose and law arises, the latter will be changed before the former is carried into effect, for a democracy cannot continue unless the people are intelligent, and real intelligence is, first of all, appreciation of law and order. ${ }^{38}$

Neither dismissive of legal doctrine nor entirely intimidated by it, planning advocates and sympathizers could and did perceive applicable legal doctrines as somewhat flexible-so long as any changes that they advocated did not overstep the acceptable framework that Bennett, Burnham, and Fisher implied. Recognizing the limits of this "law and order," planners had some confidence that their ongoing efforts to push the law to expand municipal power, eminent domain, and the police power could allow cities and their planners greater discretion in takings and land use regulation. As the New Haven planning advocates found, however, this confidence was misplaced. Seemingly flexible legal doctrines proved to be a source of ongoing frustration for the creation of their notion of the modern American city.

in the era of Lochner $v$. New York, 198 U.S. 45 (1905), to employ such conceplual detinitions of government takings of private property, see Stephen A. Siegel. Lochner Era Jurisprudence and the American Constitutional Tradition, 70 N.C. L. REv. 1, 26 n.112 (1991). The archelype of permussible municipal use of the power of eminent domain was the taking of land for a street. Since the early $19 \mathrm{th}$ century, American cities that used this practice assessed compensatıon by debılıng propery damages aganst the benefits of the new street, so that properny owners either received no money or much less than the pre-taking value of the confiscated land. See Trinity College v. City of Hartford. 32 Conn. 452 (1865) (upholding a similar compensatory scheme that set benefits off agaunst damages): In $\boldsymbol{r}$ Furman Street. 17 Wend. 649 (N.Y. 1836) (upholding a taking for streets and the compensatory scheme by which benefits were set off against damages): HeNDRIK HaRTOG. PUblic PROPERTY AND PRIVATE POWER: The CORPORATION OF THE CITY OF NEW YORK IN AMERICAN LAK, 1730-1870. al 165.68 (1983) (deseribing the process by which New York took land for streets).

37. Fisher, supra note 19, at 128.

38. Mario Manieri-Elia, Toward an "Imperial Cin": Dantel H Burnham and the Cin Beaurful Movement, in THE AMERICAN CITY: FROM THE CIVIL WAR TO THE NEW DEAL 1. 108 (Giorgio Ciucci et al. eds. \& Barbara Luigia La Prenta trans., MIT Press 1979) (1973). 


\section{B. Municipal Government}

Dillon's widely accepted explication of the law of municipal corporations also stood in the way of planners' desire to use the city government as a tool for implementing large-scale planning projects and land use regulation. His treatise was best known for "Dillon's Rule," his oft-cited call for the strict construction of municipal powers:

It is a general and undisputed proposition of law that a municipal corporation possesses and can exercise the following powers and no others: First, those granted in express words; second, those necessary or fairly implied in or incident to the powers expressly granted; third, those essential to the accomplishment of the declared objects and purposes of the corporation,-not simply convenient, but indispensable. Any fair, reasonable, substantial doubt concerning the existence of power is resolved by the courts against the corporation, and the power is denied. ${ }^{39}$

Under Dillon's Rule, a city's charter froze its municipal powers, and the flexibility that city planners might desire-an adaptable notion of "public use" for eminent domain and wide authority to regulate land use under the police power, for instance-required explicit textual authority.

Even before the first stirrings of the city planning movement, Dillon's Rule did not go unchallenged. An important jurisprudential opponent was Thomas M. Cooley, a treatise author and Michigan Supreme Court justice. In a famous 1871 concurrence, Cooley described his theory of local sovereignty and a limited role for the state:

The state may mould local institutions according to its views of policy or expediency; but local government is matter [sic] of absolute right; and the state cannot take it away. ... The right in the state is a right, not to run and operate the machinery of local government, but to provide for and put it in motion. ${ }^{40}$

Notwithstanding Cooley's opposition, Dillon's Rule remained dominant during this period. For example, an important 1923 book on municipal governance stated that the rule was "so well recognized that it is not nowadays open to question." 41

39. I DILLON, supra note $30, \S 237$, at $449-50$. On the role of Dillon's Rule in Connecticut, see Janice C. Griffith, Connecticut's Home Rule: The Judicial Resolution of State and Local Conflicts, $4 \mathrm{U}$. BRIDGEPORT L. REV. 177, 190-92 (1983).

40. People ex rel. LeRoy v. Hurlbut, 24 Mich. 44, 108, 110 (1871) (Cooley, J., concurring).

41. William Bennett Munro, The Government of American Cities 53 (1924); see clso 2 Phillip NICHOLS, THE LAW OF EMINENT DOMAIN $\$ 359$, at $990-91 \mathrm{n} .26$ (2d ed. 1917) (citing a vast number of state and federal cases for the proposition that a municipal corporation does not have the authority to take land under the power of eminent domain in the absence of express authority from the state legislature). For 
Somewhat flexible legal doctrines and a "rule" of limited municipal governance constituted a problematic context for early twentieth-century planners and planning advocates, enabling them, on the one hand, to utilize eminent domain for certain projects, but keeping them from exercising expansive powers through city government, on the other. This context would not prove conducive to a thriving city planning movement in New Haven.

\section{Establishing the Movement IN NEW HAVEN, 1907-1911}

\section{A. Commissioning the Gilbert-Olmsted Report}

According to its most vocal leader, George Dudley Seymour, the modern city planning movement in New Haven began with an open letter he wrote to the city government and New Haven citizens in June of 1907.2 Ostensibly responding to private efforts to build a hotel on the north side of the New Haven Green, the letter argued not only for reserving that part of the city's center for public buildings, but also for "the necessity of immediately securing from experts a plan along the lines of which the city may be developed by this and succeeding generations." ${ }^{43}$ From this document onward, Seymour attempted to establish that his proposals were decidedly practical and relatively modest, ${ }^{44}$ as well as necessary to keep New Haven in line with the burgeoning national and international city planning movement. ${ }^{\text {ts }}$ If led by objective experts who would be able to eliminate the internal conflicts and corruption of local government, Seymour argued, the movement would enable more efficient and efficacious "great enterprises" of municipal development.

a comparison of Dillon and Cooley that traces their infuence on and relevance to current debates on municipal governance, see Joan C. Williams. The Constuuional Vilnerability of American Lacal Government: The Politics of City Status in American Law, 1986 WIS. L. REv. 83. On the ulumate dominance of Dillon's position in jurisprudence and judicial opinion, see Gerald E. Frug. The City as a Legal Concept, 93 HARV. L. REV. 1057, $1114-15$ (1980). But see WILLAAM A. FISCHEL, REgULATORY TAKINGS: LAW, ECONOMICS AND POLITICS 276-78 (1995) (arguing that Dillon's Rule has been generally ineffective since its inception, despite regular citation in judicial opinions).

42. See Letter from George Dudley Seymour to Frank J. Rice, Mayor of New Haven (Sept. 26, 1910). reprinted in GILBERT \& OLMSTED, supra note 3, at 3-4 (identifying his open letter as the instlgator of the local city planning movement). But see ROLLIN G. OSTERWEIS. THREe CENTURIES OF NEW HAVEN, 16381938, at 390-91 (1953) (citing an earlier Seymour letter as the progentor of 20th-century cuty planning in New Haven). Seymour received support from the local media and privale individuals. See ldeas for a Ctry Beautiful by Mr. Stokes: He Highly Commends Mr. Seymour's Plan and Adds Suggesnons, Letter to the Editor, NEw HAVEN REG., June 15, 1907, at 1 (announcing the public suppon of the Yale University Secretary); The Public Interested, NEW HAVEN REG., June 7. 1907, al 6 (lauding Seymour's plan): Seymour Plan No Extravagances Says Edward A. Bowers: Modern Development of Eumopean Cintes a Proof of lt. Letter to the Editor, NEw HAVEN REG., June 18, 1907, at 2 (asserting that wide boulevards would factlate communication and business); Letter from Henry W. Farnham to George Dudley Seymour (June 3. 1907) (collection of Yale University, Ms. Gr. 442, ser. IV, box 79. fol. 1159) (supportung efforts to modemize cities and noting the need to improve city govemment).

43. Letter from George Dudley Seymour to Frank J. Rice. supra note 42. at 36.

44. See, e.g., SEYMOUR, supra note 1, at 17 (characterizing the proposal as a "business proposition" costing little and promising higher land values and a larger tax base).

45. See id. at 17-19.

46. Id. at 19. 
Less than three weeks after Seymour's letter, a meeting of interested citizens in New Haven's Colonial Hall approved a formal resolution establishing a mayor-appointed civic improvement commission "to secure experts and to go ahead with designing a working plan." ${ }^{47}$ Significantly, the Commission as proposed had no powers beyond hiring the plan's authors and had to procure for itself the necessary funding. It was not, in other words, to be a powerful municipal committee, but rather a private, philanthropic enterprise with no guarantee of any effect and no power to carry out any of its proposals.

The Commission's first meeting, held on July 1, 1907, in the Mayor's office, led to the invitation of Gilbert and Olmsted to formulate the plan. ${ }^{48}$ In addition, the meeting set in motion an ultimately successful scheme to fund the effort through subscriptions from "citizens of known public spirit."49 The idea of city planning was not threatening to New Haven's upper class, which was fully prepared to fund the enterprise and, with Seymour in charge and prominent men on the commission, to control it. There was some scattered local criticism over the next few years, aired in the local newspapers and letters to the Mayor. Generally, the criticism concerned such issues as the costs of beautification ${ }^{50}$ and the absence of ethnic and gender diversity on the commission. ${ }^{51}$ The term "beautiful," however, seemed quickly to become part of general public discourse about urban problems. ${ }^{52}$ Indeed, although the

47. City Beautiful Plan Approved, New HAVEN REg., June 20, 1907, at 3.

48. See Minutes of New Haven Civic Improvement Committee, in NEW HAVEN Civic IMPROvemENT COMMITTEE SECRETARY's BOOK at July 3, 1907 (collection of Yale University, Ms. Gr. 442, ser. IV, box $82 \mathrm{H}$, nbk. 15) (unpaginated document).

49. SEYMOUR, supra note 1 , at 49 . The city's wealthiest and most philanthropic citizens dominated the list of contributors. See GilbERT \& OLMSTED, supra note 3, at 5-6; 1907 Y.B. CHAMBER COMMERCE NEW HAVEN 56, 56-62.

50. See, e.g., Cheap Way for City Beautiful, NEw HAVEn Palladium, July 14, 1907 (collection of Yale University, Ms. Gr. 442, ser. IV, box $82 \mathrm{~A}$, nbk. 1) (including a statement by a former city alderman that supported beautification but suggested that Yale University should be forced to bear some of the expense); Planning a City Beautiful, NEW HAVEN PALLADIUM, May 12, 1909 (collection of Yale University, Ms. Gr. 442, ser. IV, box $82 \mathrm{~B}$, nbk. 3) (generally approving of the idea, but warning that the project should not be "burdensome to the taxpayers or the public treasury"). Some of the newspaper materials cited in this Note are unavailable on microfilm. Where this is the case, sources are cited to their location in the George Dudley Seymour collection at Yale University.

51. The local Italian community publicly withheld support until theater owner Sylvester Poli was finally added to the committee in October 1907. See Why No Italian? City Beautiful Commiltee Lacks in One Thing, New Haven UNion, Aug. 2, 1907, at 1; Will Give No Cash: Inalians Aroused Over City's Plans, New Haven Palladium, Aug. 3, 1907 (collection of Yale University, Ms. Gr. 442, ser. IV, box 82A, nbk. 1). The resolution adding Poli to the New Haven Civic Improvement Commission passed on October 8. See Resolution Passed at Meeting of Civic Improvement Committee, NEW HAVEN CiviC IMPROVEMENT COMMITTEE SECRETARY'S BOOK, supra note 48, at Oct. 8, 1907. In addition, officials of the New Haven Political Equality Club complained about the absence of women on the committce. See Letter from Hannah F. Sturges, President, and Annie B. Fowler, Secretary, New Haven Political Equality Club, to John Studley, Mayor of New Haven (c. Oct. 1907) (collection of Yale University, Ms. Gr. 442. ser. IV, box 81 , fol. 1188).

52. See, e.g., The City Unbeautiful, NEw HAVEN REG., July 14, 1907 (collection of Yale University, Ms. Gr. 442, ser. IV, box 82A, nbk. 1) (criticizing downtown tenement landlords for "selfish" overcrowding of tenants and poor design and upkeep of properties); New Courthouse on Sargent Site, NEw HAVEN REG., June 14,1907 , at 1 (describing the placement of the county courthouse as being within the outlines of "city 
commission originally referred to the project as a "Plan" to improve the city, not as an endeavor to make the city "beautiful," 33 within a few months, the daily New Haven Register would explicitly link the local movement to the much larger national City Beautiful movement. ${ }^{\text {st }}$ The article printed the entire charter amendment establishing the Hartford planning commission and proposed a similar municipal commission for New Haven that would be "out of the reach of party politics and bungling," "far reaching in its breadth and powers," and able to provide a "central plan" to which the "whole city" must "conform." ss

Despite such endorsements of an ambitious approach to city planning, Cass Gilbert recognized the limits of local support and the need to craft the New Haven report so as not to alienate a majority of the public. A letter from Gilbert to Seymour the following February illustrates this well:

I find that in a part of the work upon which I am especially engaged there are many questions that might be called "questions of public policy" which should receive careful consideration as well as the questions of design. Mr. Olmsted and I will try to solve them both. but when we are bringing into question the modification of existing buildings and streets grave questions will present themselves. As has been said before, "you cannot make an omelet without breaking some eggs," and so we must expect a certain amount of opposition and the best way to meet it is to prepare the way step by step. ${ }^{56}$

"Public policy" in Gilbert's parlance would seem to encompass and link a wide range of issues, from local law and politics to popular opinion. Such issues and the public's perceptions of them required deference and care.

One strategy Gilbert used was a shift in terminology to redefine the project's design and purpose. From the start, he and Olmsted had described the project to Seymour as producing "'a plan [that] must be practicable as well as beautiful, or it will fail to commend itself to the community." 1908 interview with the New Haven Journal-Courier, Gilbert made a point to remove the term "beautiful" from his and Olmsted's endeavor: "I feel that the phrase 'City Beautiful' is not a proper term to use [for this project] and it is likely to create a false impression. The development of the city should be along practical lines with reference to the convenience of traffic and

beautiful" planning).

53. Letter from the New Haven City Improvement Commuttee to Prospectuve Contnbutors (July 11. 1907) (collection of Yale University, Ms. Gr. 442, ser. IV. box 82H. nbk. 15) (solicitung contnbutions)

54. See The Scope of the "Ciry Plan," New HAVEN REg.. Oct. I. 1907, at 6

55. Id.

56. Letter from Cass Gilben to George Dudley Seymour (Feb. 1, 1908) (collectuon of Yale University, Ms. Gr. 442, ser. IV, box 79, fol. 1164).

57. Letter from Cass Gilbert and Frederick Law Olmsted to George Dudley Seymour (Feb. 21. 1910) (quoting earlier correspondence of Aug. 2, 1907), reprinted in GILBERT \& OLMSTED. supra note 3, at 7 
usefulness." ${ }^{\text {} 58}$ Gilbert apparently assumed that property owners, politicians, and voters not already associated with the local planning movement would require utilitarian reasons to accept city improvements achieved through the use of eminent domain and the police power as well as through the expenditure of public funds.

Reflecting the general movement among city planners and architects, Gilbert was likely attempting to distance his work from the earlier City Beautiful movement. That general movement had begun in the mid-1890s, and by 1907 its focus on urban parks, landscaping, monuments, and civic centers composed of clusters of public buildings was beginning to be expanded into what was known -as the "City Practical" movement." The latter placed a greater emphasis on the systematic planning of the entire city for utilitarian ends, and its leaders worked to establish a need for their professional expertise in the growing bureaucracies of municipal governments. ${ }^{60}$ It thus fell within the more general arguments of the Progressive movement, ascendent during this era, ${ }^{61}$ which sought to reform city governments of the late nineteenth and early twentieth centuries through greater municipal self-control, ${ }^{62}$ replacing

58. City Improvement: Architect Cass Gilbert Substitutes That Name for City Beautiful, New HIAVEN J.-COURIER, Apr. 8, 1908, at 3.

59. See WILSON, supra note 12, at 9. In addition to Wilson's study, another general history of the City Beautiful movement is Jon A. Peterson, The City Beautiful Movement, in INTRODUCTION to PLANNING HistoRY IN THE UNITEd STATES 40 (Donald A. Krueckeberg ed., 1983). On the shift towards the City Practical movement and its emphasis on comprehensive city planning, see SCOTT, supra note 9, at 80; and WILSON, supra note 12 , at $285-90$.

60. On the emergence of planning as a profession, see WILSON, supra note 12, at 285-86; and John L. Hancock, Planners in the Changing American City, 1900-1940, in AMERICAN URBAN HISTORY 549, 55358 (Alexander B. Callow, Jr. ed., 1969). See also FrEDERICK LAW OLMSTED, AMERICAN Civic Ass'N, CITY PLANNING 8 (1910) (arguing that "the real work of getting the results, toward which any paper plan is but a step, depends mainly upon the right sort of unremitting, never-ending work by the proper administrative officials"); SCOTT, supra note 9, at 95-100 (discussing the First National Conference on City Planning and the Problems of Congestion, held in 1909 in Washington, D.C., which explicitly differentiated itself from the City Beautiful movement).

61. On Progressivism generally, see RJCHARD HOFSTADTER, THE AGE OF REFORM (1955); and ROBEKT H. WIEBE, THE SEARCH FOR ORDER: 1877-1920 (1967).

62. Progressives pursued a number of strategies to achieve greater municipal self-control. Some argued that, to avoid the strict construction of municipal powers asserted by Dillon's Rule, state governments should pass statutes aimed at granting cities "home nule" over their own governance. See, e.g., FrANK J. GOODNOW, MUNICIPAL HOME RULE 267 (New York, MacMillan \& Co. 1895) (arguing for greater powers for local government, "subjected to a responsible administrative control"). Eugene McQuillin, whose important treatise on municipal corporations was first published in 1912, argued that municipal self-control was virtually a natural right, and a power like that of eminent domain "appertains to every independent government" and is "an attribute of sovereignty." 4 EUGENE MCQUILLIN, A TREATISE ON THE LAW OP MUNICIPAL CORPORATIONS $§ 1453$ n.3, at 3070-71 (1912). The National Municipal League, founded in 1897, argued a combination of these two positions-that state governments should allow cities to define and administer their own powers in recognition of the inherent sovereignty of the city. See HORACE E. DEMING, THE GOVERNMENT OF AMERICAN CITIES 234-37 (1909) (summarizing "The Municipal Program" of the National Municipal League). Finally, American planning proponents also noted that other western nations allowed far greater municipal use of eminent domain. See, e.g., BASSETT, supra note 27, at 4 (comparing favorably eminent domain in Canada and "European countries" to the power of the United States); L.S. ROWE, PROBLEMS OF CITY GOVERNMENT 142-43 (1908) (contrasting European cities' rights "to exercise all powers not inconsistent with state laws" and their "rigid system of administrative control" to govern state-local disputes with Dillon's strict construction of municipal powers); Robert A. Edgar, Legal 
the "bosses" of machine party politics with the centralized authority of well-trained "experts" who would be responsive to an electorate. ${ }^{63}$ Under a Progressive regime of municipal governance, legal entitlement and auhority shifted from property owners to the executive branches of municipalities, who had earlier enjoyed greater latitude in the use of their property because of open-ended regulation and uneven enforcement. With the proper authority, the new city government could "preserve the health, morals, and efficiency of the citizens" in order to counteract "the exploitations" of a few private inhabitants who operated in "wanton disregard of the rights of the many."

The movement for city improvement in New Haven gathered momentum as Seymour became more involved with the national city planning movement ${ }^{65}$ and was able to gain increased suppor from New Haven newspapers. ${ }^{66}$ In addition, the city's two most prominent civic groups, the Chamber of Commerce and the Civic Federation, became increasingly involved

Aspects of Municipal Aesthetics, 18 CASE \& COMMENT 357. 357 (1911) (noung differences between Europe, where the protection of an and natural beauty were a matter of deep state and munipal concerns, and the United States, where efforts to preserve and foster muntcipal an were "hampered by constitutional restrictions"); Fisher, supra note 19, at 127-28 (ciung Prussian statules and Paristan planning practices).

63. See, e.g., Frank J. GoOdNow, MUNicipal GoverNMiENT 386-87 (1910) (explauning the need for experts in city government, especially in devising and enforcing city plans); WiLuAM BENETT MUNRO. PRINCIPLES AND METHODS OF MUNICIPAL ADMINISTRATION 1.29 (1916) (discussing the "quest for efficiency" in modern city government). On Progressive municipal refonn generally, sec ER.NEST $S$ GriffTth, A History of american City Government. The Progressive Years aNd their AFTERMATH, 1900-1920 (1974); CLIFFORD W. PATTON, THE BATTLE FOR MUNICIPAL REFoRM (1910): and JON C. TEAFORD, THE UNHERALDED TRIUMPH: CIT GOVERNMENT IN AMERICA, 1870-1900, al 6-9 (1984). Gerald Frug argues that, in positing an objective, rational state government to control ctlles, overseen by a judiciary dedicated to protecting private property agannst both abuse by both majontanan politucs and monopolistic private economic power. Judge Dillon was in fact a precursor of the Progressive movement. although in a manner directly opposed to municıpal Progressives. See Frug. supra note $\$ 1$, at $1109-13$

64. MARSH, supra note 8, at 27.

65. In May 1909, Seymour attended the first national conference on city planning in Washington. DC. See May Bring Plan of Uniform City ro New Haven, NEw Haver REG., May 30, 1909 (collection of Yale University, Ms. Gr. 442, ser. IV, box 82B. nbk. 3) (discussing Seymour's initual relum from the conference); Mr. Seymour Gives Report at Chamber Meetmg. NEW HAVEN REG. Oct 28, 1909, at II He was also a member of the American Civic Association, see Lelter from Richard B Watrous. Secretary. American Civic Association, to George Dudley Seymour (Nov 9. 1909) (contiming Seymour's membership) (collection of Yale University, Ms. Gr. 442. Ser. IV, box 77, fol. 1133), an important natıonal organization for early city planning, see WILSON, supra note 12. at 50-52 (chronicling the development of the American Civic Association). Finally, he corresponded with numerous figures from the national movement, including John Nolen and Charles Mulford Robınson. See Lelter from John Nolen to George Dudley Seymour (Mar. 10, 1911) (collection of Yale Unwersity. Ms. Gr. 412. ser IV. box 81. fol 1190): Letter from Charles Mulford Robinson to George Dudley Seymour (Aug. 9. 1907) (collection of Yale University, Ms. Gr. 442, ser. IV, box 81, fol. 1203).

66. At the time, a plethora of newspapers served New Haven, including the Joumul-Courner. the Union, the Register, and the Palladium. The Register was often the most supportive of land use controls. Publisher John Day Jackson was among Seymour's mosi enthusiasuc supporters, and editor Everell G. Hill also supported the movement. See OSTERWEIS, supra note 42, at 398 (discussing Jackson's relalionship with Seymour); Letter from Everett G. Hill. Editor, New Haven Register, to Willam S. Pardee (Dec. 8, 1909) (collection of the New Haven Colony Historical Socsety. Ms. Ser. 59a. box V. fol 1) (accepung an invitation to join the Civic Federation committee on city improvement). Whale the Register and Journal-Courier were generally allied with the Republican Party (as was Seymour). the Union, a penny paper more aligned with the Democratic Pany, was also generally behund Seymour and cily planning. See OSTERWEIS, supra note 42 , at 398. 
in the New Haven movement, especially after the election of Isaac Ullman to the presidency of the Chamber in 1909. Ullman's address upon election focused on the City Beautiful movement, which he commended for its aesthetic and commercial goals. ${ }^{67}$ Under his leadership, the Chamber became far more active in public and private initiatives concerned with land use. ${ }^{68}$ The Civic Federation, dedicated to promoting "the civic welfare" rather than commercial interests, ${ }^{69}$ worked together with the Chamber on a number of issues, eventually including city planning. ${ }^{70}$

These elite civic organizations would play a prominent role in the conflict over building line setbacks from the curb, a relatively obscure land use regulation that became a public issue in 1909 and continued to be a source of controversy through 1913. Pitting the leadership of civic organizations, the legislative and executive branches of New Haven city government, and some property owners against one another over the legitimacy and enforcement of municipal land regulation, the conflict over building lines previewed the broader struggle over city planning that would arise after the publication of the Gilbert-Olmsted report.

\section{B. The Conflict over Building Lines: Eminent Domain and the Bureaucratic Solution}

Building lines, the distance that buildings must be set back from the curb, were the most important land use issue in New Haven during the period immediately prior to the publication of the Gilbert-Olmsted report. The

67. See Isaac M. Ullman, Address to the New Haven Chamber of Commerce (Mar. 31, 1909), in 1909 Y.B. CHAMBER COMMERCE NEW HAVEN 5, 11-12.

68. In 1909, the Committee on Town and City Improvements grew to 22 members (up from seven the previous year), and George Seymour joined its ranks. See Roster of Members in Standing Commiltee on Town and City lmprovements [hereinafter Roster of Members], in 1909 Y.B. CHAMBER COMMERCE NEW HAVEN 49, 49. Ullman's annual address the next year proclaimed the Chamber's new leadership role in public works projects in general and the City Beautiful in particular. See Isaac M. Ullman, Address to the New Haven Chamber of Commerce (Apr. 27, 1910), in 1910 Y.B. CHAMBER COMMERCE New HAVEN 5 , 7 .

69. The Council of One hundred, The Civic Fed'N of New haven, No. 7, Constitution of THE Civic Federation of NEW Haven 3 (1911).

70. Many people belonged to both the Chamber and the Civic Federation. In 1909, for instance, two of the Federation's three Vice Presidents were Chamber members, as were the Chairman and all of the Vice chairmen of the Federation's Council of One Hundred, a core group charged with initiating and producing reports on specific city problems. Compare THE COUNCIL OF ONE HUNDRED, THE CIVIC FED'N OF NEW Haven, No. 4, First annual Report of the Civic Federation of New Haven I (1910) (listing officers of the Civic Federation and the Federation's Council of One Hundred), with Roster of Members, supra note 68, at 51-59 (providing a membership list for the Chamber). For general information on the Council of One Hundred, see Henry Wade Rogers, Address of the President (May 27, 1910), in THE COUNCIL OF ONE HUNDRED, supra, at 2. One of the Council of One Hundred's publications was a report on New Haven tenement housing by Lawrence Veiller, Secretary of the National Housing Association and soon to be a leader in New York's movement to enact zoning regulations. See [LAWRENCE VEILLER], THE COUNCIL OF ONE HUNDRED, THE CIVIC FED'N OF NEW HAVEN, NO. 6, IMPROVED HOUSING FOR WAGE EARNERS 1-7 (1911). For a general discussion of Veiller's opinions of urban planning, sce SEYMOUR I. TOLL, ZONED AMERICAN 136-40 (1969). 
conflicts that arose around the establishment and enforcement of building lines foreshadowed the events that followed the release of the report, demonstrating the doctrinal and governmental limits facing both professional planners like Gilbert and Olmsted and their local patrons and supporters in prominent civic organizations.

For planning proponents, the establishment of building lines enabled cities to widen streets without having to take improved land and, therefore, to pay less compensation under the power of eminent domain. ${ }^{71}$ In addition, city planning proponents argued that building lines produced orderly and aesthetically pleasing streets by creating relative uniformity in building frontage and better enabling the circulation of light and air. ${ }^{2}$ As Edward Bassett, an attorney and planning advocate, implicitly noted in devising a litigation strategy for defending building lines against legal challenge, however, legal arguments based on health and safety concerns were more likely to succeed during this period than those based upon aesthetic purposes. ${ }^{73}$ Mandatory, uniform lines for buildings, Bassell argued, could decrease fire hazards, bring more light and air into homes and apartments, and keep noise and dust away from open windows. ${ }^{74}$ So long as a city established constitutionally permissible procedures ${ }^{35}$ and properly argued the merits of building lines under the police power, Bassett was confident that lines would, like restrictions on building heights before them, ${ }^{76}$ pass muster. ${ }^{77}$ During this period, city planning advocates throughout the country seized upon building

71. See, e.g., SHURTLEF, supra note 27, at 204 (ciling the "flexibility" that building lines allow cities that wish to widen streets in the future).

72. See, e.g., BASSETT, supra note 27. at 5 (notung both unformity and appearance as goals for building lines); FREDERICK LAW OLMSTED. Bulding Lines in the First Ward of New Haven. Report to the Joint Committee of the Civic Federation and the Chamber of Commerce on Sireets and Bulding Lines. GILBERT \& OLMSTED, supra note 3, app. at 133 (noting the better circulation of light and aur in streets with building lines).

73. See BASSETT, supra note 27, at 5. For a brief biography and full desenpition of Bassett's work on zoning in New York, see TOLL, supra note 70, at 144-16

74. See BASSETT, supra note 27, at 5.

75. The procedural issue arose in the only U.S. Supreme Court decision finding a building line ordinance unconstitutional, a decision that did not reach the issue of the constitutionality of the building lines themselves. See Eubank v. City of Richmond. 226 U.S. 137. 143-4 (1912) (sinking down a stalute because it improperly delegated to neighbors the power to establish a building linc).

76. See, e.g., Welch v. Swasey, 79 N.E. 745 (Mass. 1907) (upholding under the cily's police power a Boston ordinance providing for lower building height limits in certaun neighborhoods), aff'd. 214 U.S. 91 (1909); Attomey Gen. v. Williams, 55 N.E. 77 (Mass. 1899) (upholding building heighi restnctions in structures surrounding Boston's Copley Square), aff'd sub nom. Williams v. Parker. 188 U.S. 491 (1903): People ex rel. Kemp v. D'Oench, 18 N.E. 862 (N.Y. 1888) (finding that a municipal legislature was competent to limit the heights of dwelling houses).

77. See BASSETT, supra note 27, at 5: cf. SHLRTLEF. supra note 27. at 211-18 (providing a compendium of local charter provisions and ordinances that established the authonty of vanous cutues to establish building lines). Others were not so certain. See. e.g.. HOWARD LEE MCBAIN, AMERICAN CITY PROGRESS AND THE LAW 109-13 (1918) (claming that. while the Coun in Eubank did not reach the constitutionality of building lines per se, it was lihely "not recepuse" to thesr permissibility. and further that no cases in state cours have allowed cilies to impose bulding lines). 
line ordinances as examples of laws whose enforcement would make for a more efficient, beautiful city. ${ }^{78}$

Building lines were among the oldest forms of municipal land use controls in New Haven. ${ }^{79}$ Between 1908 and 1910, conflicts surrounding the creation and enforcement of building lines in New Haven focused on accusations made by the Mayor ${ }^{80}$ and the Corporation Counsel ${ }^{81}$ that the Board of Aldermen was violating established formal procedures for the passage of building lines, especially by granting variances for individual property owners. ${ }^{82}$ In addition, civic groups played an important role in pressing the Aldermen to enforce existing laws. ${ }^{83}$ By early 1910, the Civic Federation and the Chamber of Commerce asked Olmsted to prepare a brief proposal for building lines in the city's first ward while the Gilbert-Olmsted report was in production. The result, ultimately reproduced as an appendix to the Gilbert-Olmsted report, was general enough to provide a rationale both for strict citywide enforcement of the regulation and for the establishment of building lines suitable for the future widening of all streets where the need for their widening was foreseeable. ${ }^{84}$ Yet, Olmsted argued that for economic reasons and to preserve the legitimacy of the city's regulation of private land use, building lines should be gradually enforced over a long period of time. ${ }^{85}$

78. On the conflict over building lines in St. Louis, see Civic LEAGUe OF ST. LouIS, A CITY PLAN FOR ST. LOUIS 11 (1907), which claims that lack of enforcement of building lines resulted in widespread encroachment of property over street lines. On similar battles in New York, see GREGORY F. GILMARTIN, SHAPING THE CITY: NEW YORK AND THE MUNICIPAL ART SOCIETY 148-54 (1995), which describes the movement of the New York City Board of Estimate and individual boroughs from 1903-1912 toward strict enforcement of building lines.

79. See William S. Pardee, New Haven: Its Charter and Amendments, 1784-1914, in As to thle NEW HAVEN CITY CHARTER 1, 8 (1914) (listing the May 1826 addition to the city charter of the power to regulate building location). As the city government grew, later charters stipulated required procedures in the establishment of lines. See, e.g., NEW HAVEN, CONN., CITY CHARTER $\$ 80$ (1905) (incorporating a procedure for assessing damages caused by building lines within the mayor-appointed administrative department). On the relationship between building practices and building lines in one New Haven neighborhood, see Cappel, supra note 17, at 631-32.

80. See Communication of Mayor James B. Martin, in 1908 J. BOARD Aldermen CTTY New Haven 593, 593-98 (protesting the Aldermen's self-aggrandizement in the building line process and their granting of individual variances).

81. See id. at 594-97 (citing an opinion of Edward H. Rogers, Corporation Counsel of New Haven, detailing requirements for legal passage and implementation of building lines for "public use" and noting presumptive illegality of individual variances as an illegal taking of land for "private use").

82. In a November 1908 meeting, for example, the Board allowed three such variances for residences and businesses, enabling buildings to extend to within 18 inches of the street line. See Minutes of Board of Aldermen Meeting of Nov. 9, 1908, in 1908 J. BOARD ALDERMEN CITY NEW HAVEN 570, $571-72$.

83. See, e.g., THE COUNCIL. OF ONE HUNDRED, THE CiVIC FED'N OF NEW HAVEN, No. 1, ButLding LINES IN NEW HAVEN 6 (1909) (calling for "systematic examination of the records of the establishment of building lines" in residential and business areas and for the establishment of new lines); Letter from William S. Pardee to Frederick J. Perry, Esq., President-Elect, New Haven Board of Aldermen (Dec. 17, 1909) (collection of the New Haven Colony Historical Socjety, Ms. Ser. 59a, box V, fol. J) (pledging support from the Civic Federation for any effort the Aldermen might make to establish and maintain "proper" building lines).

84. See OLMSTED, supra note 72 , at 133.

85. See id. at 137-38. 
Given his extensive contacts in New Haven and the motives of those commissioning the pamphlet, Olmsted clearly knew of the local conflicts concerning building lines. His suggested solution to the shortcomings of municipal politics was the establishment of a permanent building lines commission, "constituted somewhat after the manner of a Park Commission and acting through a Building Line Bureau in the City Engineer's Department." $"$ "The final sentence of the Olmsted report moves even further in the direction of a consolidated, independent governmental commission employing its expertise in the development and regulation of the city: "Probably the best sort of body for dealing with this building line question would be one constituted after the manner of the Hartord City Plan Commission and with similar broad duties in addition to those of determining building lines." 87 Thus, before the publication of his and Gilbert's full report, Olmsted had used the topic of building setbacks to argue for comprehensive city planning to oversee and legitimate the city's regulation of land use.

The reading of Olmsted's report at a February 1910 meeting of the Aldermanic Committee on Building Lines caused some controversy among property owners. ${ }^{88}$ Nevertheless, local newspapers endorsed building lines, ${ }^{89}$ and the Corporation Counsel continued to remind the Board of Aldermen of the procedure necessary to establish and enforce building lines. ${ }^{90}$ Finally, in August 1911, the Board passed an act establishing a new building lines commission as a separate administrative body. however, were limited to establishing lines in new streets and in parts of streets that were widened or extended; it could only regulate existing streets by petition of the public or by the "order or direction" of the mayor or the Board of Aldermen. 92 This new, "independent" commission would be limited in its ability to establish and enforce building lines by its need to rely upon a public largely uninterested in the regulation of property, a municipal legislative

86. Id. at 138.

87. Id.

88. See Favors Commission. NEw HAVEN J.-COL'RIER. Feb. 26. 1910 (collectuon of Yale Universily. Ms. Gr. 442, ser. IV, box 82B, nbk. 3) (describung the attendance of "Interested property holders" at a meeting); Letter from George D. Watrous to George Dudley Seymour (Apr. 16, 1910) (collection of Yale University, Ms. Gr. 442, ser. IV, box 82 , fol. 1211) (providing an account of the meeung cnical of the self-interest of property owners). At least two meetungs in subsequent months replicated this conflict. See Church Street Building Lines up Last Night. NEW HAVEN REG., Apr. 20. 1910. at 3 (recounung arguments on April 19 between property owners and a civic group representattve): Gre Bricfs to Baldwin. NEw HAVEN J.-COURIER, May 4, 1910, at I (describing a May 3 meetung and the resultung call to settle legal issues through third party arbitration).

89. See, e.g., Building Lines, NEw HAVEN J.-COURIER, Apr. 19. 1910. at 6 (assertung that building lines benefit the public at large and characterizing opposition to them as consisting of "selfish" property owners).

90. See Op. Cotp. Counsel, in 1910 J. BoARd ALDERMEN CitY New Haves 316, 316-17

91. See New Haven, Conn.. An Act Estabishing a Special Commission on Building Lines $\$$ (Aug. 24, 1911).

92. Id. 
branch that until recently had engaged in the practice of granting illegal variances, ${ }^{93}$ and an executive officer who was reelected every two years. ${ }^{94}$

The Building Lines Commission, therefore, was a governmental entity intended to perform one regulatory task that the city charter had initially authorized almost ninety years before. As such, it represented a solution, born of compromise, to what the mayor, the corporation counsel, and elites affiliated with prominent civic groups considered to be a problem of land use regulation. The problem that the Commission was intended to solve was not simply doctrinal-there seemed to be no question of the city's longstanding ability to regulate building setbacks under its police power, and everyone involved seemed to agree that compensation should be paid to property holders affected by changed lines on established blocks. Nor was the problem simply an entrenched municipal government-as we have seen, despite the active resistance of the Board of Aldermen, the city continually restructured its approach to the building lines process. Ultimately, the implementation of an efficient, extensive building lines bureaucracy of the type requested by Olmsted and his prominent local supporters was limited by the fairly narrow conception of permissible public regulation of private land use in New Haven and in most of the country during this period. ${ }^{95}$

\section{THE GILBERT-OLMSTED REPORT AND AFTER: TOWARd A CITY PlanNing COMMISSION}

Gilbert and Olmsted's report, intended to describe the current state of New Haven in its entirety and to propose a plan for its future, was published less than a year before the establishment of the Building Lines Commission. ${ }^{96}$ The report's contents and influence would replicate the process seen in the conflict over building lines: the identification of a problem, the identification of available legal and political solutions, and the establishment of a bureaucratic

93. See supra notes $80-82$ and accompanying text.

94. NEW HAVEN, CONN., CITY CHARTER \& 6 (1905).

95. Ongoing conflicts between the Board and the Commission would continue even after a 1913 charter amendment that ostensibly took the Board out of the Commission's work. See New Haven, Conn., An Act Establishing a Special Commission on Building Lines $\$ 9$ (Apr. 30, 1913) (requiring only the approval of the mayor, along with the long-established processes of hearing and compensation, to make the lines proposed by the Building Lines Commission legal). As late as 1915, the Chamber of Commerce complained:

Some recent meetings of the Building Lines Commission would seem to indicate that the city feels less the meaning of [the importance of building lines] in respect to its future than it did even three or four years ago when the attempt was first made to straighten the whole matter. In some residential streets in the best quarters of the city, many people seemed to prefer to leave themselves to the mercy of any property owner who was willing to exploit his own lot at his own profit at the expense of the rest of the community.

Report of the Town and City Improvement Committee to Chamber of Commerce, in 1915 Y.B. CHAMBER COMMERCE NEW HAVEN 7, 10.

96. See GILBERT \& OLMSTED, supra note 3. 
institution unable to overcome the limits of legal doctrine and governance in the municipal context.

\section{A. The Gilbert-Olmsted Report}

The long-awaited Gilbert-Olmsted report, commissioned in 1907 and finally published in December 1910, was a handsome, comprehensive attempt to delineate the problems of the unchecked "urban metropolis of the twentieth century" and to offer a series of solutions. ${ }^{97}$ The report described a historical shift from the individualism that had well served the "pleasant little New England college town" of the nineteenth century, to the collective needs of the modern, twentieth-century city, whose dense population relied on common utilities, services, and transportation infrastructure. ${ }^{98}$ The report presented a continuum, placing outdated "individualism" on one end, successful mutual dependence in the middle, and "socialism in its controversial aspects" at the opposite extreme. ${ }^{99}$ Their report, Gilbert and Olmsted implied, was an attempt to develop the sensible middle approach, that is, to cure the chaotic excesses of an unregulated marketplace operating under a limited common law. It aimed to do so with a more expansive legal regime enforced by an expert and objective municipal apparatus.

Gilbert and Olmsted argued that this was a practical solution to a potentially dangerous problem:

People of the old New England stock still to a large extent control the city, and if they want New Haven to be a fit and worthy place for their descendants it behooves them to establish conditions about the lives of all the people that will make the best fellow-citizens of them and of their children. The racial habits and traditions, the personal experience and family training, the economic conditions and outlook. of the newer elements of the population, are such that a laissez faire policy applicable to New England Yankees is not going to suffice for them. ${ }^{100}$

According to the report, then, the core of New Haven's modern problems was the combination of modernity and race. A chart, based on findings discussed in greater detail in the report's statistical appendix, predicted that the rising birth rates and lowering death rates of the "foreign born" population would lead to a drop in the proportion of residents "native born of native parents" relative to the "foreign born" and the "native born of foreign parents." 101 The

97. Id. at 13 .

98. Id.

99. Id.

100. Id. at 15-16.

101. Id. at 15; see also id. app. at 101-05. 
goal of "civic improvement" was to improve the social stability of the city by improving the city's physical conditions:

It is the duty of the city to conserve [its] natural [economic and physical] advantages and so to control its development that the man-made conditions of living and working-the housing, the transportation, the sanitation, and all the rest of it-shall make possible the greatest productive power along with the greatest satisfaction in the work and life. ${ }^{102}$

One of the central areas needing improvement was the street system, which required an efficient and well-considered plan to create wider streets on the most important and traveled paths of traffic. The report suggested not only a comprehensive street plan, but also the creation of a powerful department of public works with authority to use the power of eminent domain to widen streets at its own discretion. ${ }^{103}$ As was the case with Olmsted's earlier report on building lines, ${ }^{104}$ however, the Gilbert-Olmsted report supported a piecemeal approach. It proposed the immediate drafting of a plan to identify those streets that would need future widening but advocated a program of implementation that would take place over an extended period of time. ${ }^{105}$ It aimed in this way to save money and protect the legitimacy of the city's use of eminent domain.

Other areas needing improvement included the maintenance of shade trees; ${ }^{106}$ unsightly overhead wires, whose vulnerability to storm created a safety hazard, especially in the city's downtown areas; ${ }^{107}$ the abundance of unsightly billboards and commercial signs; ${ }^{108}$ the sewer system; ${ }^{109}$ and the park system. ${ }^{110}$ In all of these areas, the report's descriptions and suggestions were similar: The city needed an efficient, businesslike municipal government to lead the cooperative efforts of government, private corporations, and individuals in attacking all of the city's problems at once. Nevertheless, given the authors' evaluation of the city and the efforts necessary to combat its ills, the report is striking in its modesty and its absence of concrete, systematic proposals. Moreover, unlike the Burnham-Bennett plan for Chicago, "I the

102. Id. at 16 .

103. See id. at 20-26.

104. See supra text accompanying notes 84-87.

105. See GILBERT \& OLMSTED, supra note 3 , at 26-27.

106. See id. at 30. The elms of New Haven, a local treasure of long standing, were facing extinction because of neglect and parasites. See Jonathan G. Lowet, The Elms of the Elm City, J. NEW HAvEN COLONY HIST. SOC'Y, Fall 1991, at 47, 47-60.

107. See GILBERT \& OLMSTED, supra note 3, at 32.

108. See id. at 33.

109. See id. at 33-34.

110. See id. at $34-41$.

111. See supra note 19. 
Gilbert-Olmsted report included no focused discussion of the relevant legal framework within which these improvements were to take place.

For example, the report's promotion of a piecemeal approach to street widening and building lines demonstrated a reluctance to exploit the city's power of eminent domain to its full potential. Sympathetic commentators and judges during this period cited growing legal and public sentiment favoring an expanded definition of the "public use" requirement for eminent domain to allow cities a more expansive takings power. "2 While the most significant cause of the report's hesitancy was likely the expense of compensation for extensive takings, ${ }^{113}$ Gilbert and Olmsted did not suggest ways to circumvent the payment of compensation, electing to promote a gradual approach even in areas like commercial streets, where the benefits of a wider street could offset the costs of lost property. Their hesitancy toward eminent domain, then, was attributable both to concern with legal limitations and to a desire to keep this awesome power legitimate given the likelihood of resistance by property holders (as demonstrated in the building lines dispute).

112. See, e.g., Attomey Gen. v. Williams, 55 N.E. 77.78 (Mass. 1899) (noting developments in the law of eminent domain that recognized the growing necessity of takıng land for certain public facilities. like parks and memorials, that had once been considered luxunes). aff $d$ sub nom. Williams । Parker. 188 U.S. 491 (1903); 1 NiCHOLS, supra note 41. $\$ 55$, at 16i-63 (identufyıng changes in emunent domaun that allowed takings for "public pleasure and aesthetic gratification" due to public acquieseence and judictal decisions). The 1888 and 1909 editions of another treatise on eminent doman further demonstrate that a city's takings power was beginning to expand during this ume. Compare JOUN LEWIS, A TREATISE ON THEE LAW OF EMINENT DOMAIN IN THE UNITED STATES $\$ 175$. al 243 (Chicago. Callaghan \& Co 1888) (noung in a small section on "[p]ublic parks and pleasure dnves" the utalitarian advantages of public parks for the character of a city's population, while making no mention of aestheluc purposes). with 1 JOIN LEwis. A TREATISE ON THE LAW OF EMINENT DOMAIN IN THE UNTTED STATES $\$ 271$. at $539-40$ (3d cd. 1909) (adding the words "[a]esthetic purposes" to the renumbered section, cilting numerous cases decided since 1888 , and finding the legal question of whether "aesthetic purposes" could fall under the "public use" requirement of eminent domain to be unsettled).

In the most sanguine treatise statement about the prospects for further expansion of eminent domain for city planning and the municipal arts, Eugene McQuillın claumed in 1912 that recent legislatıve efforts in cities refiected the fact that a

desire to render the urban centers more attractive has found a firm lodgment in the popular mind. It is destined to increase with the years, and in the development of the law in this respect courts will be inclined to give a broader interpretation to such regulations. and finally sanction restrictions imposed solely to advance matenally attractuveness and artistic beauty

3 MCQuillin, supra note 62, \& 929, at 2022-23. Nevertheless. MeQuillın also noted that al the ume, aesthetic considerations could not alone support a caty's use of the police power or eminent domasn to restrict or take property. See id. at 2021; see also Nichots, supra note 18. $\$ 232$, at 269-70 (noung a gradual change in American law and culture toward allowing takıngs for an aesthetic purpose. so long as there was a showing of "material advantage to the public"). For an even more confident statement. from 1911, claiming that municipal corporations could take land for aesthetic purposes under eminent domain power, see Edgar, supra note 62. at 365. See also SHLRTLEF, supra note 27. at 21 (asserning that. with public support, using eminent domain for aesthetic purposes could be legal): FraNK BaCK( $S$ WILLidis. THE LAW OF CITY PLANNING AND ZONING 19-20 (1922) (citing vanous state coun decisions from 1907. 1915 for the proposition that, in reviewing muncipal government acts performed under the ctiy's police and eminent domain powers, courts had been influenced by "current usage and custom" as ucll as popular opinion); Wilbur Larremore, Public Esthetics. 20 HARV. L. REV. 35.36 (1906) (desenbing an altemaluve means of allowing "aesthetic" takings under emınent doman).

113. See OLMSTED, supra note 72, at 137-38 (citing savings for the cily through deferral of compensation and reduced interest payments). 
Similarly, in addressing the overbuilding of tenement housing that led to overcrowded apartments cut off from light and air, Gilbert and Olmsted proposed neither to regulate private tenements under the police power nor to erect public housing-precisely the solutions posed by housing expert Lawrence Veiller, whose report on tenement conditions in New Haven would be published later in 1911. ${ }^{114}$ Instead, the report offered its standard suggestions of parks and streets, proposing that the city acquire the interior land of large tenement blocks and either form playgrounds or cut new streets in order to open the land to "a better class of development."

Besides building lines, the two areas for which the report emphasized regulation of private land use were commercial advertising and building heights around the New Haven Green. In both cases, Gilbert and Olmsted presented more conservative suggestions than they believed appropriate to the situation. The report suggested that unsightly billboards could be treated as nuisances. ${ }^{116}$ It also noted the potential "offence to public morals or health through the nature of the advertisement," 117 thereby justifying invocation of the police power. The report ultimately concluded, however, that such arguments would be rejected by the "somewhat ultra-conservative" courts that were "cautious about interfering arbitrarily with an individual's use of his own property," and by "easy-going" residents afraid to risk "getting the reputation of being fault-finding busybodies." 118 As an alternative, Gilbert and Olmsted proposed a licensing and taxation program (which was never implemented after the report) on billboards and similar commercial advertising-a regulatory scheme to be sure, but well short of their ultimate goal of outlawing the "irritating and annoying" sights. ${ }^{119}$

While writing the report, Olmsted and Gilbert corresponded extensively about the report's passages on building height limitations. Their correspondence reveals a great deal about what they considered to be possible under current legal doctrine, and within public conceptions of legitimate limits on private land use. They debated both the degree to which the heights of buildings should be regulated and how the report should advise New Haven to implement such regulation. The letters reveal that Gilbert and Olmsted considered the way in which Washington, D.C., and European cities fixed limitations (according to street width), as well as Boston's elementary form of zoning (enforcing different height limits in its business district than in the remainder of the city, placing the strictest height limits around Copley

114. See VEILLER, supra note 70.

115. GILBERT \& OLMSTED, supra note 3, at 37-39.

116. See id. at 33.

117. Id.

118. Id.

119. Id. 
Square) ${ }^{120}$ Despite this consideration, however, they decided upon a minimal approach, suggesting a limit of a hundred feet for buildings around the Green, instead of the ninety-foot limits in Copley Square. ${ }^{2 !}$ As to the remainder of the city, the final report stated, "Limitations of height are needed in all our cities, but they should be as flexible as is consistent with the thorough practical protection of the common interest in light and air." ${ }^{\prime 22}$

The vagueness of this statement was quite deliberate. In March 1910 , Gilbert had suggested to Olmsted that the question should be left to New Haven residents and officials "to thrash it out among themselves as they undoubtedly would in any case no matter which our recommendation might be." 123 By calling attention to the need for limitations, they aimed to ensure that "local conditions will develop what restriction can reasonably be fixed." 124 By limiting their discussion, however, they were able to keep their report fairly moderate in approach and their conception of planning neither radical nor exploitative with respect to contemporary legal doctrine and assumptions about property rights.

The report's attempt to articulate a middle path between nineteenth-century "individualism" and "socialism in its controversial aspects" was meant to resolve the conflict between private rights and public needs, and it demonstrates the spoken and unspoken limits that planners perceived in proposing schemes to discipline the excesses of the modern city. Between "ultra-conservative" courts, an "easy-going" public, and legal doctrines only beginning to expand to meet the needs of city planners lay a relatively circumscribed approach to comprehensive city improvements in New Haven.

\section{B. 1911-1913: Reactions, Aftermath, and a Bureaucratic Plan}

The limits that New Haven planning advocates faced following the report's release in attempting to formulate government institutions to implement land use regulations and initiate municipal projects paralleled the limits that Gilbert and Olmsted perceived in their effort to devise plans within existing legal doctrine. As with the conflict over building lines, the wider call for city planning that the report articulated remained largely unfulfilled despite an administrative solution that temporarily placated those leading the campaign for planning.

120. See Letter from Olmsted Bros. to George Dudley Seymour (Mar. 21. 1910) (collection of Yalc University, Ms. Gr. 442, ser. IV, box 81, fol. 1194) (enclosing a draft of a section on building height limitations, with descriptions of Boston and Washıngton's regulations): Letter from Fredench Law Olmusted to Cass Gilbert (Mar. 1, 1910) (collection of Yale University. Ms Gr. 4.42, ser. IV, bor 81, fol 1194) (agreeing to allow the city flexibility in heıght regulations, except for butldings that surround the Green)

121. GILBERT \& OLMSTED, supro note 3, at 51 .

122. Id.

123. Letter from Cass Gilben to Frederick Law Olmsied (Mar 2. 1910) (collection of Yale University. Ms. Gr. 442, ser. IV, box 81 , fol. 1194).

124. Id. 
Upon its release, the report was summarized in a number of papers, including the Union ${ }^{125}$ and the Register. ${ }^{126}$ Laudatory editorials in both attempted to anticipate and answer potential criticisms of the report by focusing on the practical and economic improvements it promised. For example, the Union wrote:

There has been much fun poked at, and considerable ridicule heaped upon the so-called idea of the "City Beautiful." There will undoubtedly be many who will only be too willing to criticise as impractical the plan proposed by this commission to improve New Haven. As it unfolds itself, the proposed plan does seem a bit stupendous and will probably awe those who cannot see much further than the noses on their own faces. Yet there is nothing absolutely impossible in the report, and it is the product of the ability and experience of several men. ${ }^{127}$

Similarly, the Register praised the report as "practical," argued that the "City Beautiful" label was no longer appropriate as a result, and exhorted the public to read the report and work together to improve the city. ${ }^{128}$ Another Register editorial, entitled How We Can Afford It ${ }^{129}$ praised Seymour for his willingness in interviews after the report's release to engage in "business talk at last, [and] to take the cold utilitarian view" of the program of city improvement. ${ }^{130}$ The editorial reported Seymour's emphasis that, because improvements would undoubtedly raise property values in surrounding areas, the city's tax base would expand, thus raising city income and replenishing the city treasury. ${ }^{131}$

Soon after the report's release, a series of events took place that demonstrated to Seymour and other planning advocates the need for a centralized, organized approach to city development and land use controls. In March 1911, the New York, New Haven \& Hartford Railroad changed the proposed location of its new station closer to downtown. ${ }^{132}$ As a critical element in both the transportation system and the city center of the early twentieth-century city, the railroad station's site and the street approaches to it were crucial to the city's layout and circulation of traffic and commerce. Indeed, the Gilbert-Olmsted report had proposed widening and making more

125. See The City Beautiful, NEW HAVEN UNION, Feb. 13, 1911, at 4.

126. See The Civic Improvement Commission's Report, NEw HAVEN REG., Feb. 26, 1911, at 6.

127. The City Beautiful, supra note 125.

128. The Civic Improvement Commission's Report, supra note 126.

129. How We Can Afford It, NEW HAVEN REG., Mar. 12, 1911 (collection of Yale University, Ms. Gr. 442 , ser. IV, box $82 \mathrm{C}$, nbk. 5).

130. Id.

131. See id. (referring to an interview with Seymour in Road's Plans Would Benefir City Greatly, NEW HaVEN ReG., Mar. 12, 1911, at 2).

132. See Railroad Depot on Chapel Street Now Says Road, New HaveN REG., Mar. 12, 1911 (collection of Yale University, Ms. Gr. 442, ser. IV, box 82C, nbk. 5). 
direct the approach to the station from the center of downtown New Haven, the Green. ${ }^{133}$

In the aftermath of the railroad's announcement, however, the solution that the report was supposed to represent-the expert, deliberative approach to city improvements, and the freedom from the vested interests of individual property holders and the vagaries of the marketplace-immediately seemed impossible to attain. Property owners at the proposed new Chapel Street site insisted on selling at prices that the railroad deemed "utterly unreasonable." 13 The property necessary for the new approaches could not be taken under the power of eminent domain because the land was not essential for the railroad's right of way. ${ }^{135}$ The attorney for the affected property holders argued against any attempt to condemn his clients' land. ${ }^{136}$ Owners of commercial land in the vicinity of both the existing station and the proposed Chapel Street site fought for their competing interests in the potential move. ${ }^{137}$ The Register criticized the proposed site as certain to cause congestion and a needless waste of land that could be improved and beautified. ${ }^{138}$

A downturn in the railroad's economic fortunes in the summer of 1911 delayed plans for the new station indefinitely. ${ }^{139}$ By January, however, plans for a new station were revived by an offer from landowners near the proposed station to donate parcels of their property for a street approach from downtown. ${ }^{140}$ For Seymour, this haphazard method of planning and situating so important a public building was an indication of the need for a central authority to guide and advise the city as to its best long-term interests. ${ }^{1+1} \mathrm{~A}$ few weeks later, he interpreted this experience as proof of the need for a municipal planning commission and characteristically announced this conclusion on the pages of the Register in a long article called Ciny by lts Errors Has Shown the Need of "Plan Commission." rashly conceived, "piecemeal" approach to city improvement that the proposed railroad depot epitomized, Seymour claimed that a commission would have rationally and efficiently considered alternatives, thereby minimizing the costs

133. See GILBERT \& OLMSTED, supra note 3, at 54-58.

134. Road's Statement, New HAVEn REG.. Mar. 12. 1911 (collecuon of Yale Universily. Ms Gr 42. ser. IV, box $82 \mathrm{C}$, nbk. 5).

135. See Many Cirizens Praise the Chapel Sireer Sure. NEW HAVEv J.-COL'RIER. Mar 14. 1911, al I But see The Depot Complication. NEW HAVEN J.-COL'RIER. Mar. 14. 1911, at 6 (stating that the ralload could take land under its power of eminent doman).

136. See Chapel Street Site Is Urged at Harfford. New HAVEN Reg.. Mar. 29. 1911. at I

137. See George Dudley Seymour, City by lts Errors Has Shown Need of "Plan Commission," New HAVEN REG., Feb. 11, 1912 (collection of Yale University. Ms. Gr. 42. ser. IV. box 82C. nbk. 5) (noting that "any one owner knows that he may block the enture project by standing out for a higher pnce")

138. See We Can't Have $h$, NEW HAVEN REG. Mar. 13. 19l1, at 6.

139. See New Depot Given Knockout in Sweeping Halt Called on Expendstures by Mellen. NEW HAVEN REG., Aug. 26, 1911, at 1.

140. See Repon Favors Land Offer: G.D. Seymour Issues a Warning. NEw Havex REG . Jan 22. 1912 , at 1 .

141. See id.

142. Seymour, supra note 137. 
associated with the project and maximizing the benefits to the public. ${ }^{143}$ His article reproduced in its entirety the Hartford charter amendment creating its planning commission and invited citizens, civic groups, and the city government to work together to pass similar legislation. ${ }^{144}$ Leading local figures proclaimed their support for Seymour's plan. ${ }^{145}$

Three months later, at its first meeting after the publication of the Gilbert-Olmsted report, the New Haven Civic Improvement Commission resolved to work toward a charter amendment to establish a city plan commission modeled on Hartford's. ${ }^{146}$ Seymour continued his attempt to gain support for the planning concept in a long September article in which he linked the current planning movement to New Haven's history of land use since the colonial era, ${ }^{147}$ and in a December article tying what he saw as the diverse problems in New Haven-including the city's position as "one of the most conservative communities in the United States," the ongoing controversy over the placement of the train station, the need for further recreation facilities, and the regulation of building heights along the New Haven Green-to the lack of a city planning commission. ${ }^{148}$ His work and that of others clearly had some effect on the Board of Aldermen, which passed the charter amendment at its November 25, 1912 meeting. ${ }^{149}$ To ensure the amendment's passage by the state legislature, its authors copied much of the language from Hartford's amendment, and the Chamber of Commerce strongly encouraged its interested members to travel to the state capitol on the day of the vote. ${ }^{150}$ The state legislature approved the amendment in May 1913. ${ }^{\text {s1 }}$ In November, as secretary of the new Commission, Seymour wrote the Board of Aldermen that he and his fellow members hoped "to be of service in an advisory way to the Board of Aldermen, to whom [we] will report on all matters referred to the

143. Id.

144. See id.

145. See Civic Leaders Endorse a "Plan Commission" Here, NEw Haven ReG., Feb. 12, 1912, at 1 (including praise from the Mayor, President of the Board of Aldermen, and the Dean of the Yalc Law School).

146. See Minutes of the New Haven Improvement Commintee, in NEW HAVEN CITY IMPROVEMENT COMMITTEE SECRETARY'S BOOK, supra note 48, at May 9, 1912.

147. See George Dudley Seymour, Building City Our Forefathers Planned, NEw Haven ReO., Scpt. 15, 1912 (collection of Yale University, Ms. Gr. IV, ser. 78, box 82D, nbk. 7). On the value of his work on the history of town planning in America and New Haven as a form of propaganda, Seymour had written to his brother, "The paper is rather prolix and repeats things about New Haven but by repetition are things put home." Letter from George Dudley Seymour to Denison Seymour (Nov. 8, 1912) (collection of Yale University, Ms. Gr. 442, ser. IV, box 78, fol. 1150).

148. George Dudley Seymour, Our City and Its Big Needs, New HAVEN J.-CourIER, Dec. 16, 1912, at 6.

149. See Committee on Legislation, Report to the Board of Aldermen of New Haven on the City Plan Commission, in 1912 J. BOARD ALDERMEN CITY NEW HAVEN 333.

150. See, e.g., Letter from Lewis S. Welch, Chairman, Chamber of Commerce Committee on Town and City Improvements, to George Dudiey Seymour (Feb. 19, 1913) (collection of Yale University, Ms. Gr. 442, ser. IV, box $82 \mathrm{H}$, nbk. 15).

151. See Act of May 28, 1913, 1913 Conn. Spec. Acts 897, 897-98 (amending the charter of New Haven and creating a city plan commission). 
Commission, as promptly as circumstances and the character of the questions submitted permit." 152

Chamber of Commerce President Ullman was pleased, and proclaimed in his yearly address:

With the creation of a City Plan Commission, many of the mistakes that New Haven has made in the past, in the laying out of streets, the erection of buildings, and the establishment of building lines, or the failure to do so, will be avoided. And this Commission, if it comes into existence, will prove most valuable in our future City planning. ${ }^{153}$

Lewis Welch, in his annual report of the Chamber's Committee on Town and City Improvements, proclaimed his pride in the Chamber's role in the state's approval of the planning amendment, and claimed that the turnout of Chamber members at the state committee hearing on the measure was "the best demonstration of New Haven's civic spirit that has been offered in recent years." 154

Seymour, Ullman, and those supporters who envisioned an active commission would soon be disappointed, however. Across the country during this period, planning commissions proved largely ineffectual. City governments, even where cities were given the authority from state legislatures to establish the commissions, were hesitant to grant much authority or funding to the newfangled agencies. In Connecticut, Hartford's planning commission, so envied by planning advocates in New Haven, was a hybrid public-private institution composed of ex officio governmental officials and private citizens with limited power and autonomy from the local government. ${ }^{\text {1ss }}$ Similar problems occurred nationally. Although thirty-six cities had established planning commissions by 1913 , these new administrative agencies remained largely advisory bodies; their main functions, according to even their proponents, were to coordinate and facilitate the efforts of more powerful governmental bodies. ${ }^{156}$ When faced with public referenda on their recommendations, city planning commissions occasionally failed to garner public support. ${ }^{157}$ Even the model enabling act for local city planning bodies

152. City Plan Comm'n, Communicanon to the Board of Aldermen of New Haven. in $1913 \mathrm{~J}$ BOARD ALDERMEN NEW HAVEN 591, 592.

153. Isaac M. Ullman, Address to the New Haven Chamber of Commerce (Apr 30. 1913), in 1913 Y.B. Chamber COMmerCE New HAVEN 3,6.

154. Lewis S. Welch, Annual Report of the Committec on Town and City Improvements (Mar 26. 1913), in 1913 Y.B. ChaMber COMMERCE NEW HAVEN 11,11

155. See FOGLESONG, supra note 10. a1 225. In addition, the Hanford commission was underfunded, and its official repon was not published until four years after its establishment. See Scotr. supra note 9. at $80-81$.

156. See SHURTLEF, supra note 27, at 190-206 (providing a compendium of representaluve state and city acts enabling or establishing city planning commissions, with only one providing for a commission with mandatory review powers for all public works projects).

157. See, e.g., id. at 197 (discussing the fallure of Seattle's 1912 referendum on a planning 
produced by the 1913 national city planning conference proposed a commission that was only an advisory executive department, with no responsibility or authority to act on its own. ${ }^{158}$

As with both the national experience of city planning commissions and New Haven's precursor, the Building Lines Commission, the City Plan Commission's authority was circumscribed by design. Worse, the advisory powers that the latter enjoyed were at the mercy of the mayor and city legislature. Its funding was not fixed, ${ }^{159}$ thereby limiting its ability "to employ expert advice and to incur such other expenses as may be necessary."160 Other than to prepare "a comprehensive plan"161 (the scope of which was left undefined), the Commission's duty was only to consider and report on all public projects, and no administrative agency or government actor was required to pay attention to its declarations. ${ }^{162}$ Its self-generated proposals had no weight of authority, ${ }^{163}$ and although the city could act through the Commission in using its power of eminent domain, it was not forced to do so. ${ }^{164}$ The mayor's control over the composition of the Commission's membership gave him virtually complete authority over planning: Not only was he one of the five members, but he also appointed its two unpaid citizen members and its representative of the city administration, the city engineer. ${ }^{165} \mathrm{~A}$ member of the Board of Aldermen, elected by the Board, filled the fifth and final post. ${ }^{166}$ At the last minute, Seymour had attempted to increase the number of non-officeholders on the Commission, to make it less "political" and thus less subject, he thought, to vested property interests; but he failed to do so. ${ }^{167}$

In his letter of resignation in 1924, Seymour complained bitterly of the Commission's impotence during his tenure. ${ }^{168}$ Arguing that the city continued to ignore areas that the Gilbert-Olmsted report identified as needing attention for planning purposes-including the railroad, the harbor, streets, and parks-Seymour referred New Haven's mayor and newspaper readers who

commission).

158. See id. at 143 (quoting Report on Proceedings of the FifTH National Conference on City PLANNING 248-50 (1913)).

159. See Act of May 28, 1913, §§ 2-3, 1913 Conn. Spec. Acts 897, 897 (amending the charter of New Haven and creating a city plan commission).

160. Id. § 2, at 897 .

161. Id.

162. See id. §5, at 897.

163. See id. \& 7, at 898 .

164. See id. $\S 8$, at 898 .

165. See id. \&1, at 897.

166. See id.

167. Letter from Louis Welch, Chairnan, Chamber of Commerce Committee on Town and City Improvements, to George Dudley Seymour (Mar. 3, 1913) (collection of Yale University, Ms. Gr. 442, ser. IV, box 82 , fol. 1212).

168. See Seymour Quits Board, supra note 1, reprinted in SEYMOUR, supra note 1, at 598. 
came upon his open letter to the document whose creation he helped to initiate and organize:

I never urged anything but a "City Practical,"-the great aim of cityplanning. It was my misfortune and I think the City's misfortune, to have the sensational slogan "City Beautiful" fastened upon the project by the newspapers, by ultra-conservatives and by those whose chief pleasure resides in deriding progress and who delighted to dub my project "the dream of a dreamer." Against all such opposition then and now I call attention to the New Haven Report. ${ }^{169}$

The local movement that advocated modern city building through centralized planning, best represented in the pages of the Gilber-Olmsted report, had confronted the "ultra-conservatives" in municipal governance, in the interpretation and enforcement of legal doctrine, and among local property owners, and had lost.

\section{CONCLUSION}

Early city planning in New Haven, like similar local movements around the country, proved to be a remedy that existed largely on paper-on the pages of a relatively modest report and in legislative acts and charter amendments. The failure of this effort stemmed in part from planning advocates' inability to control the political process and to build widespread popular support for land use reform. ${ }^{170}$ Yet, these are only partial explanations, which fail to confront the historical limitations of the available legal doctrine and forms of municipal governance. While not entirely disabling planning practice, these limitations constrained what planners could propose-as demonstrated in the Gilbert-Olmsted report-and what municipal commissions could enact and enforce-as demonstrated by the Building Lines Commission and City Plan Commission.

In 1914, one year after the establishment of the City Plan Commission in New Haven, Seymour produced a pamphlet critical of a downtown marquee

169. Id., reprinted in SEYMOUR, supra note 1 , at 598.

170. City planning movements in New Haven and throughout the country were led largely by elites. As others have argued, these movements attempled to impose moral order on urban masses, see BoYER. URBAN MASSES, supra note 6, passim, disciplinary order on urban subjects and the growing metropolis, see BOYER, DREAMING, supra note 6, passim, and capitalist order on the sites of indusinal production. see FOGLESONG, supra note 10 , passim. Indeed, numerous segments of the local population-not only those property owners who were fearful of what they perceived to be an invasion of their inviolable nghts. but also working class immigrant groups fearful of dislocation and increased policing of their neighborhood by the city had ample reason to be wary of the rise of city planning. Nevertheless. Andrew Cappel's argument that increased land use regulations in the pre-zoning era falled because they were unnecessary and broadly unpopular - an assertion that he bases on the fact of elite control of the New Haven movement and his detailed study of reasonably coordinated land use patterns in one white. middle class residential area in northeast New Haven -is unpersuasive. See Cappel, supra nole 17. 
built by the Shartenberg \& Robinson store. ${ }^{171}$ Asserting that the rights of the public in the sidewalk and in the air and light obstructed by marquees were paramount over the rights of property owners, the pamphlet, like so many of Seymour's similar efforts, failed to have a discernible effect on the city's physical environment. On the cover of the copy of the pamphlet that he kept, Seymour wrote: "It is of course certain that in time we shall have ordinances controlling the use of the streets by private interests. This 'Open letter' will bear fruit sometime."172

Consistent with Seymour's prediction, the fortunes of city planning would change as the century progressed and national city planning advocates began to share Seymour's hope for the future. As William Bennett Munro, a professor of municipal government at Harvard, put it, "[T]he mere establishment of advisory boards is a considerable step in the right direction; the mandatory powers will doubtless come in due time." ${ }^{\prime 73}$ The concerted efforts of planning advocates to push for changes in legal doctrine and municipal governments, and to coordinate and support their efforts nationally, certainly helped to push the legal limits faced by city planning in what Munro characterized as the "right direction." 174 Thus, in 1926, the U.S. Supreme Court found comprehensive municipal zoning to be constitutionally permissible, a decision that constituted the most important legal development for city planning in the early part of the twentieth century. ${ }^{175}$ That same year, New Haven passed its first zoning ordinance, despite public resistance and criticism. ${ }^{176}$

171. GEORge DUdLEy SEYMOUR, AN OPEN LETtER TO THE HONORABLE BOARD OF ALDERMEN OF

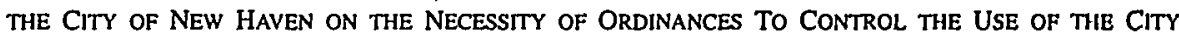
STREETS BY PRIVATE INTERESTS (c. 1914) (collection of Yale University, Ms. Gr. 442, ser. IV, box 78, fol. 1151). For Seymour's later recollections of the events surrounding the pamphlet, see Seymour Quits Board, supra note 1, reprinted in SEYMOUR, supra note 1, at 593, 598.

172. SEYMOUR, supra note 171 (handwritten note on cover of pamphlet).

173. MUNRO, supra note 63 , at 45.

174. For a striking illustration of the growing sophistication of planning advocates in legal issues, compare Charles Mulford RoBINSON, THE IMPROVEMENT OF TOWNS AND CITIES 76-93 (1902), which describes ordinances limiting billboards and other public advertising, and id. at 271-94, which describes city governments, with Charles Mulford Robinson, City-Planning Legislation, in CITY PLANNING 404 (John Nolen ed., 1916), which provides a more sophisticated, detailed, and technical list of city planning ordinances and relevant legal doctrines.

175. See Village of Euclid v. Ambler Realty Co., 272 U.S. 365 (1926). Ambler Realty summarized and utilized planners' ideological and legal arguments particularly well in its description of an emerging urban crisis and its assertion that the solution lay in a new regime of private land use controls. Justice Sutherland's majority opinion found the U.S. Constitution to be a flexible document that both authorized zoning and set limits on potentially more intrusive controls that "clearly" were not within the Constitution's realm of the permissible. Id. at 386-87.

176. See New Haven City Plan Comm'N, supra note 15, at 3 (describing the first New Haven zoning ordinance); and Forbush, supra note 15, at 45-46, 83 (describing the history of the first New Haven zoning ordinance and focusing on the success of local manufacturers in protecting their own interests at the expense of the general public). In 1924, Seymour predicted that the local zoning ordinance, which was then being formulated, would be more effective as part of a coordinated plan, but complained that due to the lack of an adequately funded and authorized planning commission, this would not occur. See SEYMOUR, supra note 1 , at 600 . 
Fifty years after Seymour's initial effors, New Haven would emerge as a leader in urban renewal and city planning under Mayor Richard Lee, who would graft upon the city bureaucracy a redevelopment establishment responsible only to the executive and responsive only to a select few constituencies. Lee's far more intrusive efforts to redevelop through massive relocation, destruction, and public and private construction would have seemed an impossible dream to the proponents of the City Beautiful and the City Practical. ${ }^{177}$

In the wake of the legal and governmental transformations wrought by the New Deal, World War II, and the Great Society, city planning was able to bring about the kind of reorganization of the community unimaginable to proponents of land use regulations in early-twentieth-century New Haven. ${ }^{178}$ Despite their relative lack of success, by hesitantly challenging "ultraconservative" courts, traditional doctrines, and inefficient and self-dealing municipal governments, early city planning proponents in New Haven and elsewhere helped to initiate the process by which the laws and practices of municipal control over private land use changed. ${ }^{179}$

177. On New Haven urban renewal under Lee generally. see sources cited supra note 22 . On the structure of the Lee administration specifically, see Norman I. Fainstein \& Susan S. Fannstcin. New Haven: The Limits of the Local State, in Restructuring THE CITY: THE POLTICAL ECONONY Of URBAN REDEVELOPMENT 37-39 (Susan S. Fainstein et al. eds., 1983).

178. On the relationship between the law of early city planning and that of post-war planning. see Carol M. Rose, Planning And Dealing: Piecemeal Land Controls as a Prablem of Local Legitumacy. 71 CAL. L. REV. 837, 839 (1983), which characterizes the City Besutuful movement as providing the "roots" of modern land use law.

179. See id. 
